sciendo Порівняльна професійна педагогіка 9(2)/2019 Comparative Professional Pedagogy 9(2)/2019

DOI: $10.2478 /$ rpp-2019-0012

Postdoctoral Researcher in Pedagogy, Associate Professor, VIKTOR MOZGOVYI

Mykolaiv Branch Office of Kyiv National

University of Culture and Arts

Address: 17 Dekabrystiv St., Mykolaiv, 54017, Ukraine

E-mail: viktoriya-1972@ukr.net

\title{
PEDAGOGICAL ANIMATION: EDUCATIONAL PRACTICES OF UKRAINE AND POLAND
}

\begin{abstract}
The article analyzes the essential characteristics of the concept of pedagogical animation in the context of Ukrainian and Polish educational practices, specifies the peculiarities of pedagogical animation, studies the vectors of developing the phenomenon under study and compares relevant approaches to its implementation in the systems of the Ukrainian and Polish teacher education. The conducted analysis on the interpretation of the concept of pedagogical animation concludes that the Ukrainian education system unilaterally uses the functionality of this phenomenon. Pedagogical animation is mainly a part of the problems of socio-pedagogical, socio-cultural, cultural and leisure nature and issues of physical education organization. The underestimated importance of the phenomenon under study in the context of the educational process can significantly affect the implementation of the analyzed programme for updating the system of general secondary education. The use of pedagogical animation as a method of interaction between teachers and students based on child-centeredness and partner pedagogy contribute to implementing the main components of the Concept of the New Ukrainian School. The range of using pedagogical animation in educational practices of Polish teachers is more expanded. Along with the traditional socio-cultural and activity-based one, pedagogical animation is an integral part of the educational process. High social standards in the country urge pedagogical science and practice to implement a variety of training programmes, which incorporate animation skills as components of professional competencies. The variability of special pedagogies in Polish educational practices highlights the issue of pedagogical animation development both at theoretical and methodological levels. The results of the comparative analysis show that the use of pedagogical animation in Ukrainian and Polish educational practices contributes to developing pedagogical interaction at various stages of education, namely from preschool education to adult education. The development of pedagogical animation and its justification as a didactic structure will help to bring this phenomenon to a new level of educational significance and promote it as advanced pedagogical experience.
\end{abstract}

Keywords: pedagogical animation, pedagogy of playing, animation activities of teachers, professional teacher training, Ukrainian and Polish experience.

\footnotetext{
АНОТАЦІЯ

У статті досліджено сутнісні ознаки поняття «педагогічна анімація» 6 контексті освітніх практик України і Польщі. Деталізуючи характерні особливості педагогічної анімації, визначено вектори розвитку досліджуваного феномену, порівняно підходи щодо його реалізаиії у системах вітчизняної і польської педагогічної
} 
sciendo Порівняльна професійна педагогіка 9(2)/2019 Comparative Professional Pedagogy 9(2)/2019

освіти. Проведений аналіз тлумачень поняття «педагогічна анімація» дає підстави стверджувати, щзо вітчизняна система освіти дещяо однобічно використовує функиіональні можливості вказаного феномену. Здебільшого педагогічна анімація $\epsilon$ складовою проблем сочіально-педагогічного, сочіально-культурного, культурнодозвіллєвого характеру та питань організації фізичного виховання. Недооцінювання важливості досліджуваного феномену саме в контексті освітнього процесу може суттєво вилинути на реалізацію заявленої програми модернізації системи загальної середньої освіти. Використання педагогічної анімації як методики взаємодї вчителя й учнів на засадах дитиночентризму та партнерської педагогіки сприяють реалізації основних компонентів Концепиії Нової української иколи. Більи розииреним $\epsilon$ спектр використання педагогічної анімачії в освітніх педагогічних практиках польських педагогів. Поряд із традиційністю сочіально-культурної діяльної педагогічна анімація $\epsilon$ складовою процесу навчання. Високі соиіальні стандарти краӥни мотивують педагогічну науку $і$ практику реалізовувати різноманітні програми підготовки фахівців, у яких навички анімачійної діяльності є складовими професійних компетениій. Варіативність спеціальних педагогік в освітніх практиках Польщі актуалізує питання розвитку педагогічної анімачії як на теоретичному, так $і$ на методичному рівнях. За результатами порівняльного аналізу зроблено висновок, щяо використання педагогічної анімації в освітніх практиках Украӥни і Польщі сприяе розвитку педагогічної взаємодії на різних етапах освіти особистості - починаючи від дошкільної освіти і закінчуючи програмою освіти дорослих. Розвиток педагогічної анімації та ї̈ обтрунтування як дидактичного комплексу сприятиме виведенню вказаного феномену на новий рівень освітньої значущості та популяризацію ї̈ як передового педагогічного досвіду.

Ключові слова: педагогічна анімація, педагогіка гри, анімачійна діяльність учителя, професійна підготовка вчителя, досвід України і Польщі.

\section{INTRODUCTION}

In Ukraine, pedagogical science has radically changed the vectors of theoretical and practical development being focused on the European education systems. Given the rather high social standards of most European Union countries in the realm of education, there is probably no reason to doubt the correctness of the path chosen. The openness of the Ukrainian teacher education system and its ability to renew itself is a guarantee of rapid adaptation to the requirements for the modern educational process. In addition, specific attention should be paid to the development of the synthesized aspects of pedagogical action in some EU countries, which combine the activities completely different in terms of specificity and functionality into a single professional training. In the context of the current research, this is pedagogy and animation.

\section{THE AIM OF THE STUDY}

The research aims to comparatively analyze scientific approaches to forming the essence of such concepts as pedagogical animation and animation pedagogy and to identify the vectors for the scientific elaboration of these phenomena in the context of implementing Ukrainian and Polish educational practices.

\section{THEORETICAL FRAMEWORK AND RESEARCH METHODS}

It is precisely a certain affinity between scientific views of teachers, the corresponding theoretical basis for developing coherent research topics which lie behind the comparative analysis of educational practices in Ukraine and Poland. In the context of 
Ukrainian research, the synthesis of animation and pedagogical activity is defined as certain vectors of social pedagogy (L. Lokhvytska, N. Maksymovska, Yu. Vozna et al.); drama pedagogy (L. Ivanova, L. Lymarenko, A. Vitchenko, L. Zimakova et al.); sports pedagogy (V. Naumchyk, A. Sydoruk, A. Vindiuk et al.).

As for the studies of Polish teachers, the most developed vectors of the synthesis of pedagogy and animation are the pedagogy of playing (pedagogika zabawy) (I. CzajaChudyba, E. Kędzior-Niczyporuk, B. Sułkowski, D. Wosik-Kawala) and socio-cultural animation (animacja spółeczno-kulturalną) (B. Jedlewska, A. Kobylarek, U. Lewartowicz).

The following methods were used to realize the aim of the study: analysis, synthesis, comparison and generalization of findings by Ukrainian and Polish teachers, which is a characteristic feature of comparative pedagogy.

\section{RESULTS}

Before studying the development vectors of such concepts as pedagogical animation and animation pedagogy, it is vital to analyze the semantics of the term "animation" in the Ukrainian and Polish context.

The analysis of Ukrainian educational practices in the use of animation in the context of pedagogical activity shows that the term "animation" has become rather common due to the modernization of preschool, general and vocational education. However, one should pay attention to the fact that the number of interpretations of the term in pedagogical dictionaries (Honcharenko, 1997; Flehontov, 2013; Honcharenko ta in., 2000) and encyclopedias (Kremen, 2008) is still limited.

The Great Explanatory Dictionary of Modern Ukrainian Language does not consider the concept of animation to be a component of the subject-subject interaction (Busel, 2002). The essence of this concept is explained as follows: 1) a method of creating a series of pictures, drawings, coloured spots, dolls or silhouettes in separate movement phases, which animate the dead forms of movement on the screen; 2) animated cartoons (Busel, 2002, p. 31).

Analyzing research findings by Ukrainian scholars, the author of the article traced some interdependence between the concepts of animation and social pedagogy. This fact indicates a certain traditionalism of scientific views on the concept of animation in the context of organizing leisure activities for different age categories. In the Explanatory Mini Dictionary of Social Pedagogy and Social Work, L. Lokhvytska (2017) interprets the term "animation" as "a conscious action aimed at implementing certain actions to improve the social climate of a particular environment, create an atmosphere of creativity, help people adapt to social changes, promote their integration into the socio-cultural space, encourage them to interact and understand people in the group" (p. 15).

Exploring social and pedagogical activities in the field of leisure and, especially, animation approach, N. Maksymovska (2013) characterizes animation as "a prosocial catalyst of social creativity, social subjectivity, whose introduction through progressive development improves sociality; as motivation in action and a way of creating relevant conditions for revealing the essential needs of the individual, which improves the society" (p. 192). The scholar emphasizes the fact that "animation as a socio-pedagogical phenomenon has its own characteristics, namely promoting interaction, as well as a spiritual and consolidating character; manifesting motivated personal subjectivity and hidden positive potential, ensuring direct human involvement, stimulating initiative and activity, providing opportunities for social self-realization" (Maksymovska, 2013, p. 193).

One should also pay particular attention to Yu. Vozna's research on the significance of socio-cultural animation in the context of social and pedagogical activities. 
Indeed, the author analyzes the very concept of pedagogical animation, which implies "a pedagogically organized interaction between a social educator and a pupil in the leisure field, through which they satisfy and develop health-improving, recreational, cultural and educational, cultural and creative needs and interests; and which create relevant conditions for forming social activity of the individual who is able to change the surrounding reality" (Vozna, 2015, p. 27). Further, she determines the functions of pedagogical animation, namely "relaxation as the recovery of spent energy, psychosomatic relaxation, rest, emotional discharge; communication as an interaction; cognitivization as the discovery of something new; creativization as the creative development in action and motion" (Vozna, 2015, p. 27).

The term "animation" is more widely used in educational pedagogical practices in Poland. The first thing to note here is the content of the concept of animation, which is interpreted in the Universal Dictionary of the Polish Language (Uniwersalny słownik języka polskiego) (Uniwersalny stownik, 2007) as follows: "1) a technique of producing films, which implies creating a series of drawings in different movement phases, which, at the time of the film's release, create the impression of a holistic action or living; 2) controlling puppets in the puppet theatre or shooting them in a puppet film;3) motivation towards activity: animation of cultural life in the working environment" (Uniwersalny stownik, 2007, p. 15). In contrast to the Ukrainian interpretation of the term "animation", however, the Polish one explains its content in the context of the subject-subject interaction.

The analysis of Polish scientific works proves that it is necessary to consider theoretical views of A. Kobylarek on the variability of using animation both in the sociocultural sphere and education. The author indicates, "in addition to understanding sociocultural animation, there is the same narrow (educational) approach which emphasizes the introduction and promotion of stimulating the individual's consciousness. In this regard, socio-cultural animation is viewed as a certain influence aimed at education and training of individuals, groups and social communities through culture. All this depends on the actions which help to reveal creative potential, stimulate and motivate creative activity of the individual and thus integrate people with each other and with the surrounding world, sustain spiritual development, self-development and purposefulness of learning and multiplication of culture, supporting and promoting its relevance in society" (Kobylarek, 2006, p. 35). The author also proves the significance of pedagogical animation, namely "in the socio-cultural animation, the cultural aspect is rightly shifted to the background since almost all animators have studied at pedagogical faculties and obtained corresponding humanities-oriented specializations" (Kobylarek, 2006, p. 36).

The study of U. Lewartowicz on socio-cultural animation as a method of preventing cultural exclusion is no less interesting. Analyzing the essence of the problem, she indicates, "socio-cultural animation has been employed in the Polish pedagogical theory and practice for almost 30 years. As a result, it has become a method of not only cultural activity but also of sociology, education and has been incorporated in such spheres of life as economics, sports, entertainment and leisure. The above-mentioned branches constantly disclose new animation contexts. However, it must be noted that the key positions for it have long remained unchanged, namely the category of social inclusion" (Lewartowicz, 2018, p. 200).

It is important to take into account some very powerful scientific studies of Polish teachers on the effectiveness of pedagogy of playing (pedagogika zabawu). When justifying the essence and functionality of pedagogy of playing in personal and professional training of teachers, I. Czaja-Chudyba (2006) indicates, "in psychological and pedagogical contexts, playing is a specific kind of activity which occurs naturally, expresses creativity, freedom 
sciendo Порівняльна професійна педагогіка 9(2)/2019 Comparative Professional Pedagogy 9(2)/2019

and independence and is characterized as a situation, personal position or activity" (p. 11). This motivates the author to consider the pedagogy of playing as an effective method of working with different age categories, namely from preschoolers to adults. In her conclusions, the author draws attention to the significance of pedagogy of playing in professional and personal training of teachers and emphasizes that "during professional teacher training, a dual function associated with playing is implemented: firstly, it is a form of self-improvement; secondly, it implies developing skills to use playing when designing the didactic and educational process" (Czaja-Chudyba, 2006, p. 77). It must be noted that the author absolutely does not use the term "animation" in the descriptions of pedagogy of playing. The author of the article assumes that this is the researcher's own position, although the idea of pedagogical animation can be traced through its very nature.

\section{CONCLUSIONS}

It is beyond argument that the scope of one scientific article does not give grounds for final conclusions. This was not the main objective of this research either since it aimed to compare the vectors of theoretical comprehension of pedagogical animation in Ukrainian and Polish educational practices. According to the results of the comparative analysis, one can conclude that Ukrainian educational practices are mainly focused on the use of pedagogical animation within the limits of the social and pedagogical activity or specifically in the format of sports pedagogy, which has long existed as a playing-based form of learning. The topic of pedagogical animation is gradually becoming relevant in the context of organizing educational, cultural and leisure activities for schoolchildren. However, it must be noted that the overwhelming number of topics in this context relates to culturological issues within the educational process. It is a pity that pedagogical animation cannot be fully and completely integrated into the educational process. Despite the fact that the Concept of the New Ukrainian School has radically changed the approaches to organizing pedagogical interaction, pedagogical animation is still not employed in Ukrainian educational practices. It is also much contributed by the "isolation" of the Ukrainian pedagogical science from teaching placement. Therefore, it is completely groundless to neglect scientific findings by Ukrainian teachers ("The fundamentals of pedagogical mastery", "The directional spectrum of pedagogical action", etc.), which may become the starting point for implementing pedagogical animation, precisely within the educational process, and ensuring the implementation of effective pedagogical interaction. The implementation of the principles of partnership pedagogy motivates Ukrainian teachers towards the expediency of using pedagogical animation within the framework of the basic form of education, that is a modern lesson.

As for using pedagogical animation in Polish educational practices, it must be noted that there is a certain identity with the Ukrainian models for implementing sociocultural and socio-pedagogical activities. However, specific attention should be paid to the broad thematic elaboration of pedagogy of playing and the current approach to training animators with the aim to implement relevant activities, namely professional training of animators is provided by pedagogical faculties. It is also necessary to focus on practical approaches of Polish higher education institutions to synthesizing animation activities with various pedagogical specializations, namely "Animation of free time and active leisure"" (Animation czasy wolnego i rekreacja ruchowa); "Pedagogical and art therapy" (Terapia pedagogiczna $\mathrm{z}$ arteterapią); "Pedagogy of preschool and primary education and pedagogy of creativity" (Pedagogika przedszkolna i wczesnoszkolna z pedagogik kreatywności). The author of the article believes that such an approach and the mentioned variability contribute 
sciendo Порівняльна професійна педагогіка 9(2)/2019 Comparative Professional Pedagogy 9(2)/2019

to developing pedagogical animation as a practical component of the educational process at different stages of organizing pedagogical interaction. This experience should be studied more in detail and implemented in Ukrainian pedagogical practices, taking into account all the peculiarities and specifics of Ukrainian educational institutions.

The prospects for further studies should be aimed at conducting a comparative analysis of animation pedagogy's functionality in Ukrainian and Polish educational practices and teacher's pedagogical actions in this process.

\section{REFERENCES}

1. Busel, V. T. (2002). Velykyi tlumachnyi slovnyk suchasnoi ukrainskoi movy. Kyiv: Perun.

2. Chernyshova, Ye. R., Huzii, N. V., \& Liakhovytskyi, V. P. (2013). Terminolohichnyi slovnyk $z$ osnov pidhotovky naukovykh ta naukovo-pedahohichnykh kadriv pisliadyplomnoi pedahohichnoi osvity. Kyiv: Universytet menedzhmentu osvity.

3. Czaja-Chudyba, I. (2006). Pedagogika zabawy w osobowym i profesjonalnym przygotowaniu do zawodu nauczyciela. Kraków: Wydawnictwo Naukowe Akademii Pedagogicznej.

4. Flehontov, N. M. (2013). Korotkyi slovnyk aktualnykh pedahohichnykh terminiv. Kyiv: KNUTD

5. Honcharenko, S. U. (1997). Ukrainskyi pedahohichnyi slovnyk. Kyiv: Lybid.

6. Honcharenko, S. U., Ziaziun, I. A., Nychkalo, N. H., Dubynchuk, O. S., Talaluieva, N. O., Molchanova, A. O., \& Lukianova, L. B. (2000). Profesiina osvita: slovnyk. Kyiv: Vyshcha shkola.

7. Jedlewska, B. (2008). Miejsce i ranga animacji spółeczno-kulturalnej w edukacji pedagogów w polskich uniwersytetach. V D. Hertsiuk, \& R. Kucha (Red.), Pedagogiczna oświata na Ukrainie $i$ w Polsce: realia i perspektywy (s. 271-290). Lviv: LNY im. I. Franka.

8. Kobylarek, A. (2006). Animacja społeczno-kulturalna jako metoda aktywizacji środowiska lokalnego. Techniki animacji. V E. Zierkiewicz (Red.), Tworzyć, zmieniać, aktywizowa ... Animacja społeczno-kulturalna jako mobilizowanie potencjału indywidualnego i przeciwdziałanie bezradności społecznej (s. 35-47). Wrocław: Mar-Mar.

9. Kremen, V. H. (2008). Entsyklopediia osvity. Kyiv: Yurinkom Inter.

10. Lewartowicz, U. (2018). Animacja społeczno-kulturalna jako metoda przeciwdziałania wykluczeniu z kultury. Wydziat Pedagogiki i Psychologii, XXXI (1), 199-208.

11. Lokhvytska, L. V. (2017). Tlumachnyi slovnyk-minimum iz sotsialnoi pedahohiky ta sotsialnoi roboty (2-he vyd.). Ternopil: Mandrivets.

12. Maksymovska, N. O. (2013). Sotsialno-pedahohichna diialnist u sferi dozvillia: animatsiinyi pidkhid. Visnyk LNU imeni Tarasa Shevchenka, 23 (282), I, 186-196.

13. Uniwersalny słownik języka polskiego. (2007). Waszawa: Readers Digest Przegląd.

14. Vozna, Yu. V. (2015). Sotsiokulturna animatsiia u konteksti sotsialnopedahohichnoi diialnosti. Zbirnyk naukovykh prats Kamianets-Podilskoho natsionalnoho universytetu imeni Ivana Ohiienka. Seriia: Sotsialno-pedahohichna, 25, 24-33.

15. Wosik-Kawala, D. (2008). Przygotowanie przyszłych pedagogów do stosowania pedagogiki zabawy w pracy z dziećmi i młodzieżą. V D. Hertsiuk, \& R. Kucha (Red.), Pedagogiczna oświata na Ukrainie $i$ w Polsce: realia i perspektywy (s. 313-320). Lviv: LNY im. I. Franka. 